\title{
3D model related to the publication: New turtles from the Late Cretaceous of Monte Alto-SP, Brazil, including cranial osteology, neuroanatomy and phylogenetic position of a new taxon
}

\author{
Ferreira Gabriel S. ${ }^{1,2,3 *}$, Iori Fabiano V. ${ }^{4,5}$, Hermanson Guilherme ${ }^{1,6}$, Langer Max C. ${ }^{1}$ \\ ${ }^{1}$ Laboratório de Paleontologia de Ribeirão Preto, Faculdade de Filosofia, Ciências e Letras de Ribeirão Preto, Universidade de São Paulo, \\ Avenida Bandeirantes 3900, 14040-901, Ribeirão Preto, SP, Brazil \\ ${ }^{2}$ Senckenberg Center for Human Evolution and Palaeoenvironment (HEP) at Eberhard Karls Universität, Sigwartstraße 10, 72076 Tübingen, \\ Germany \\ ${ }^{3}$ Fachbereich Geowissenschaften der Eberhard Karls Universität Tübingen, Hölderlinstraße 12, 72074 Tübingen, Germany \\ ${ }^{4}$ Museu de Paleontologia "Prof. Antonio Celso de Arruda Campos", Centro de Artes, Praça do Centenário, 15910-000, Monte Alto, SP, Brazil \\ ${ }^{5}$ Museu de Paleontologia "Pedro Candolo", Estação Cultura, Praça Farmacêutico Bruno Garisto, 15890-000, Uchoa, SP, Brazil \\ ${ }^{6}$ Department of Earth Sciences, University of Oxford, South Parks Road, Oxford OX1 3AN, UK \\ *Corresponding author: gsferreirabio@gmail.com
}

\section{Abstract}

The present 3D Dataset contains the 3D model analyzed in the following publication: Ferreira, G.S., F.V. Iori, G. Hermanson, and M.C. Langer 2018. New turtles from the Late Cretaceous of Monte Alto-SP, Brazil, including cranial osteology, neuroanatomy and phylogenetic position of a new taxon. PalZ. https://doi.org/10.1007/s12542017-0397-x

Keywords: carotid circulation, microcomputed tomography, Neuroanatomy, Pleurodira, Podocnemidoidae

Submitted:2017-07-09, published online:2018-02-01. https://doi.org/10.18563/m3.3.2.e2

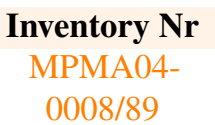

nventory Nr
MPMA04-
$0008 / 89$

Taxon
Yuraramirim
montealtensis

\section{Description \\ Skull lacking} both premaxillae and squamosals, and parts of other bones.

Table 1. Associated model. MPMA: Museu de Paleontologia de Monte Alto, SP, Brazil.

\section{INTRODUCTION}

This project contains 3D model and a phylogenetic matrix related to the article "New turtles from the Late Cretaceous of Monte Alto-SP, Brazil, including cranial osteology, neuroanatomy and phylogenetic position of a new taxon". The sample of 3D models refers to the brain, endosseous labyrinth, cranial nerves and vessels endocasts of a new side-necked turtle, Yuraramirim montealtensis, obtained using micro CT scan images (see Fig. 1 and table 1). Regarding fossil turtles, there are only virtual reconstructions for pan-cryptodirans or taxa outside the crown-group in the literature (e.g. PaulinaCarabajal et al. 2013, 2017) and, as such, this represents the first soft tissue digital reconstruction for an extinct pleurodire. Additionally, the nexus file included contains the phylogenetic analysis data presented in the original article that includes the new taxon (see "Methods").

\section{METHODS}

The 3D surfaces were extracted semi-automatically within Materialise Mimics (18.0) using the segmentation threshold selection tool. The 3D surface models are provided in .ply format, and can therefore be opened with a wide range of freeware. The nexus file included contains a phylogenetic-data matrix of 39 taxa and 95 characters compiled from literature (e.g. Gaffney et al. 2011; Cadena 2015; Ferreira et al. 2015; further literature may be found within the original article) and was analyzed on TNT (Goloboff et al. 2008) using parsimony as the search criterion.

\section{ACKNOWLEDGEMENTS}

Grant sponsor: Fundação de Amparo à Pesquisa do Estado de São Paulo (FAPESP). Grant number: 2014/25379-5 and 2016/03934-2 to GSF, 2016/03373-0 and 2016/17116-0 to GH, and 2014/03825-3 to MCL.

\section{BIBLIOGRAPHY}

Cadena, E.A. 2015. A global phylogeny of Pelomedusoides turtles with new material of Neochelys franzeni Schleich, 1993 (Testudines, Podocnemididae) from the middle Eocene, Messel Pit, of Germany. PeerJ 3, e1221. https://doi.org/10. 7717/peerj.1221 


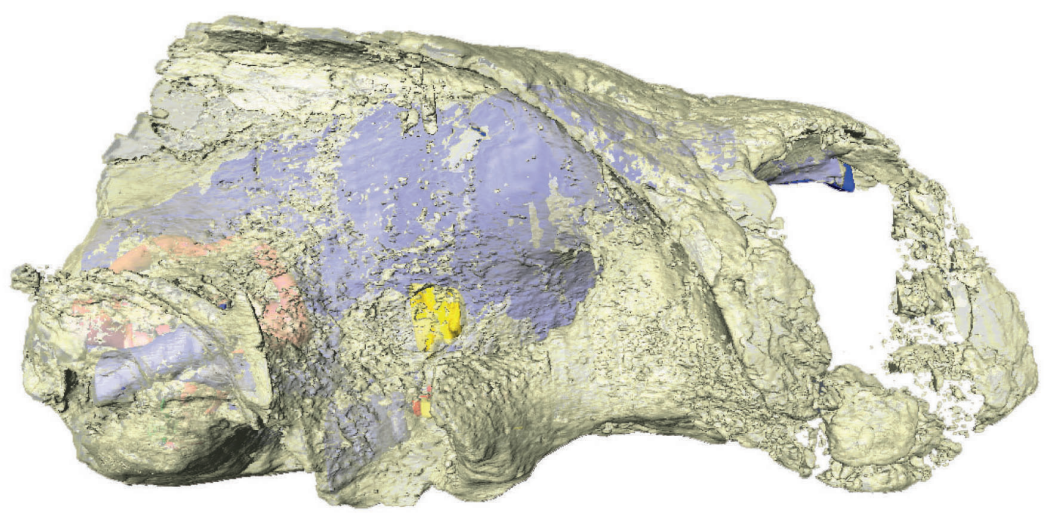

\section{$1 \mathrm{~cm}$}
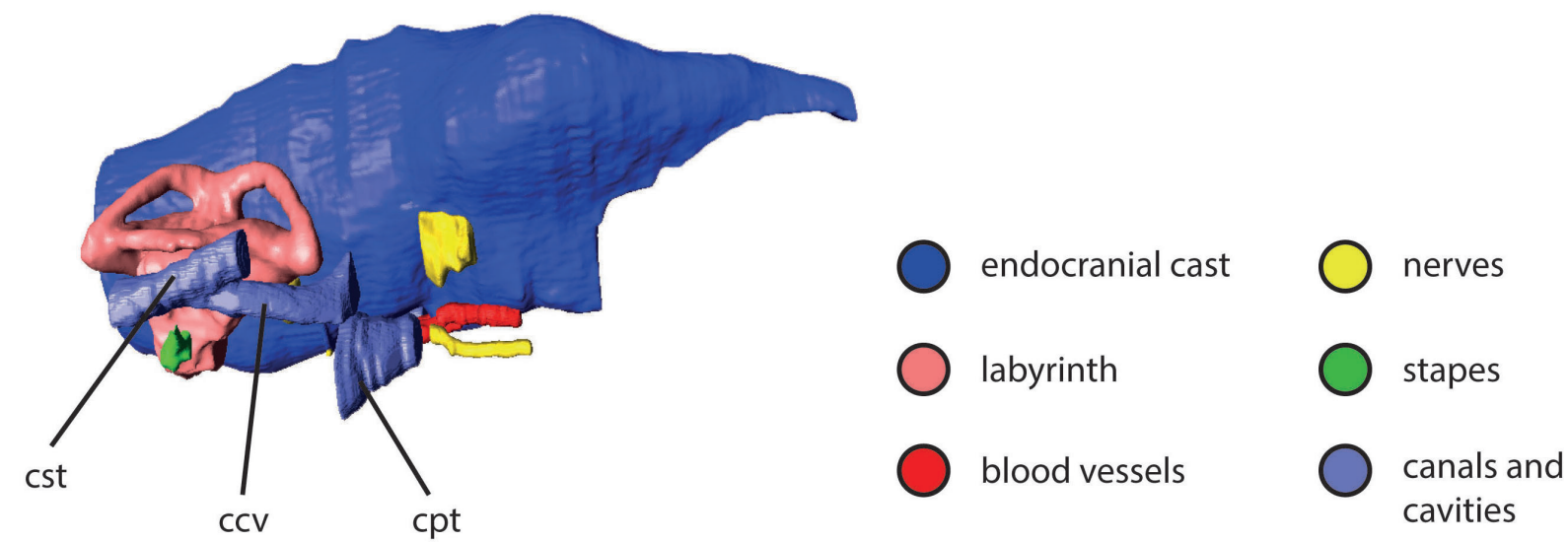

Figure 1. Virtual endocasts reconstructed for Yuraramirim montealtensis, a new side-necked turtle. Abbreviations: ccv, canalis cavernosus; cpt, cavum pterygoidei; cst, canalis stapedio-temporalis.

Carabajal, A.P., J. Sterli, J. Müller, and A. Hilger 2013. Neuroanatomy of the marine Jurassic turtle Plesiochelys etalloni (Testudinata, Plesiochelyidae). PLoS ONE 8(7), e69264. https://doi.org/10.1371/journal.pone.0069264

Ferreira, G. S., A. D. Rincón, A. Solórzano, and M. C. Langer 2015. The last marine pelomedusoids (Testudines: Pleurodira): a new species of Bairdemys and the paleoecology of Stereogenyina. PeerJ 3, e1063. https://doi.org/10.7717/peerj .1063

Ferreira, G.S., F.V. Iori, G. Hermanson, and M.C. Langer 2018. New turtles from the Late Cretaceous of Monte AltoSP, Brazil, including cranial osteology, neuroanatomy and phylogenetic position of a new taxon. PalZ. https://doi.org/ 10.1007/s12542-017-0397-x

Gaffney, E. S., P. A. Meylan, R. C. Wood, E. Simons, and D. A. Campos 2011. Evolution of the side-necked turtles: the family Podocnemididae. Bulletin of the American Museum of Natural History 350, 1-237. https://doi.org/10.1206/350.1

Goloboff, P. A., J. S. Farris, and K. C. Nixon 2008. TNT, a free-program for phylogenetic analysis. Cladistics 24, 774-786. https://doi.org/10.1111/j.1096-0031.2008.00217.x
Paulina-Carabajal, A., J. Sterli, J. Georgi, S.F. Poropat, and B.P. Kear 2017. Comparative neuroanatomy of extinct horned turtles (Meiolaniidae) and extant terrestrial turtles (Testudinidae), with comments on the palaeobiological implications of selected endocranial features. Zoological Journal of the Linnean Society, https://doi.org/10.1093/zoolinnean/zlw024 